This article is licensed under the Creative Commons Attribution-NonCommercial 4.0 International License (CC BY-NC) (http://www.karger.com/Services/OpenAccessLicense). Usage and distribution for commercial purposes requires written permission.

\title{
Phenytoin Toxicity Treatment with Haemodialysis in Epilepsy due to Glioblastoma Multiforme: Case Report and Review of the Literature
}

\author{
Karishma Sharma ${ }^{\mathrm{a}} \quad$ Aditi Vakil $^{\mathrm{b}}$ Ahmed Sokwala $^{\mathrm{a}}$ Dilraj Sokhi $^{\mathrm{a}}$ \\ aDepartment of Medicine, Faculty of Health Sciences, Aga Khan University (East Africa) \\ Medical College, Nairobi, Kenya; ${ }^{5}$ School of Medicine, University of Nairobi, \\ Nairobi, Kenya
}

\section{Keywords}

Phenytoin toxicity · Haemodialysis · Drug interactions

\begin{abstract}
Phenytoin is one of the most commonly used anticonvulsants in the developing world, but lack of monitoring and concurrent medications can easily lead to toxicity. We report the case of a 35-year-old female on phenytoin for symptomatic epilepsy due to previously treated glioblastoma multiforme, who presented with status epilepticus 1 week after being treated for a urinary tract infection. She was loaded with phenytoin and levetiracetam as per emergency protocol but had a persistently low level of consciousness, and her preloading phenytoin level result came back in the toxic range. She was managed conservatively, but after 4 days with no change she was dialyzed and her level of consciousness improved within $24 \mathrm{~h}$, allowing for safe discharge home shortly after. Our case illustrates the option of haemodialysis in phenytoin-toxic patients who do not improve with conservative measures or who may need urgent reduction due to potentially fatal complications of phenytoin toxicity.
\end{abstract}




\section{Case Reports in Neurology}

Case Rep Neurol 2019;11:344-350

DOI: $10.1159 / 000504470$

Sharma et al.: Phenytoin Toxicity Treatment with Haemodialysis in Epilepsy due to

Glioblastoma Multiforme: Case Report and Review of the Literature

\section{Introduction}

Phenytoin is one of the oldest anticonvulsants available, and due to its availability and cheap price is commonly used for treating epilepsy in the developing world, including Kenya. At therapeutic levels, phenytoin follows first-order kinetics, which changes to non-linear zeroorder pharmacokinetics in the upper therapeutic and toxic range [1], with levels $>20 \mathrm{mg} / \mathrm{L}$ being associated with toxicity. The risk of toxicity with phenytoin is high: it has a narrow therapeutic index, is a hepatic enzyme inducer, and is highly protein bound, all of which make it highly susceptible to saturated metabolism by interacting with other drugs [1]. The first documented case of phenytoin toxicity is from 1948, in a patient with epilepsy for 4 years who took an intentional overdose [2]. The risk factors associated with toxicity are acute overdose, toxicity from dose changes or drug error, altered physiology such as in renal failure/cirrhosis, drug-drug/drug-disease interactions, and unintentional ingestion of phenytoin such as from cocaine adulterated with phenytoin [2]. The treatment of phenytoin toxicity is mainly supportive [2], but there are guidelines that suggest consideration of haemodialysis (HD) in cases of coma and incapacitating ataxia [3]. We describe here a case with phenytoin toxicity who was safely treated with HD, which resulted in a good outcome.

\section{Case Presentation}

A 35-year-old female was admitted urgently with status epilepticus to our regional tertiary referral centre. She was known to have epilepsy secondary to glioblastoma multiforme which had been resected 6 years prior, followed by postsurgical chemo- and radiotherapy, and with consequent dysphasia and right-sided weakness requiring home-based nursing with her husband. Her seizures were well controlled on phenytoin $100 \mathrm{mg}$ three times a day until this presentation. Further history revealed that she had been treated for a urinary tract infection with nitrofurantoin for 1 week leading to this admission. On assessment, her Glasgow Coma Scale (GCS) score was 8/15, and she had a tachycardia of $110 \mathrm{bpm}$, with otherwise normal vital observations. Her blood sugar level was normal at $5.6 \mathrm{mmol} / \mathrm{L}$, and cardiovascular/respiratory and abdominal examinations were unremarkable. As per our emergency department protocol, she was immediately loaded with $1 \mathrm{~g}$ of phenytoin intravenously, diazepam $2.5 \mathrm{mg}$ intravenously, then levetiracetam $1 \mathrm{~g}$ intravenously, and received some intravenous fluid resuscitation before being transferred to the high dependency unit.

Investigations revealed normal full haemogram, urea, potassium, creatinine, peripheral blood smear for malarial parasites, blood culture, electrocardiogram, and unenhanced computed tomography scan of the head. She had a hyponatremia of $126 \mathrm{mmol} / \mathrm{L}$ (normal range: $135-145 \mathrm{mmol} / \mathrm{L}$ ), and urinalysis was turbid with leukocytes. Her phenytoin levels came back at $24 \mathrm{~h}$ and were markedly elevated at $65.6 \mu \mathrm{g} / \mathrm{mL}$ (normal range: $10-20 \mu \mathrm{g} / \mathrm{mL}$ ). Phenytoin was therefore withheld and levetiracetam continued as maintenance at $250 \mathrm{mg}$ twice a day intravenously. We added empiric piperacillin-tazobactam for treatment of urinary tract infection. She did not have any further convulsions in the ensuing days, but her GCS score remained depressed at 10/15. Repeat serum sodium revealed a further drop to $122 \mathrm{mmol} / \mathrm{L}$, with a raised urine osmolality of $567 \mathrm{mOsm}$ (normal range: $<100 \mathrm{mOsm}$ ), confirming syndrome of inappropriate antidiuretic hormone which was managed with $3 \%$ hypertonic saline (tolvap- 


\section{Case Reports in Neurology}

Case Rep Neurol 2019;11:344-350

DOI: $10.1159 / 000504470$

2019 The Author(s). Published by S. Karger AG, Base www.karger.com/crn

Sharma et al.: Phenytoin Toxicity Treatment with Haemodialysis in Epilepsy due to Glioblastoma Multiforme: Case Report and Review of the Literature

tan was prescribed but could not be afforded by the spouse). However, despite correction of sodium levels, the patient's GCS score remained depressed and her phenytoin levels remained elevated at $72.9 \mu \mathrm{g} / \mathrm{mL}$. With no other reversible cause found and after consulting with chemical pathology and nephrology specialists, we proceeded with HD to reduce the phenytoin level more rapidly. The patient was dialysed for $4 \mathrm{~h}$ using a low-flux dialyser with no heparin or ultrafiltration, and levetiracetam was administered after the session (as this antiepileptic drug is otherwise dialysed out).

After one session of HD the phenytoin levels dropped to $47.3 \mu \mathrm{g} / \mathrm{mL}$; assuming a linear reduction in levels [3], the predicted level would have been $59.5 \mu \mathrm{g} / \mathrm{mL}$, which suggests the dialysis offered a further $16.7 \%$ reduction in levels (Fig. 1). Before dialysis, the patient's GCS score was improving by 1 point every 2 days, but after dialysis this rate of improvement was doubled at 4 points in 4 days. The patient was back to her normal neurological status on day 13 , with a GCS score of $15 / 15$, and was discharged home on levetiracetam.

\section{Discussion}

Our patient had been on phenytoin for control of her seizures for many years, but then decompensated after being treated for a urinary tract infection. Nitrofurantoin is known to interact with phenytoin but by reducing levels of the drug [4]. It is possible that there may have been confusion with the capsules leading to an inadvertent overdose, or concomitant use of other over-the-counter medicines that led to the toxicity. The increased epileptogenesis may have been a combination of both the significant hyponatraemia as well as the paradoxical toxic effects of phenytoin, especially if the level is $>50 \mathrm{mg} / \mathrm{L}$ [5], and intravenous phenytoin is one of the more common causes of in-hospital hyponatraemia [6].

In addition to standard resuscitative measures, activated charcoal can be used if the patient presents early without a depressed mental state [2], but the timing of overdose in our patient was not known and in deliberate overdose cases has been demonstrated to have occurred a few days prior to reaching a comatose state $[7,8]$. Reducing the dose of, or altogether replacing, phenytoin can result in improvement of the toxicity symptoms relatively quickly, especially where there is polypharmacy and therefore more drug-drug interactions, e.g., in an elderly person [9]. However, extracorporeal removal of toxins can become necessary to reduce the risk of potentially fatal toxicity complications such as organ failure [8].

The commonest technique reported is HD, and it is sometimes instituted almost immediately [10]. Other techniques that have been used in phenytoin toxicity include continuous veno-venous haemofiltration [11], charcoal haemoperfusion [12], and the molecular adsorbent recirculating system [13]. Although theoretically plasma exchange and haemoperfusion would more efficiently remove phenytoin from the circulation, intermittent HD is the preferred extracorporeal treatment in phenytoin poisoning, with haemoperfusion being an acceptable alternative if HD is not available and where the molecular adsorbent recirculating system is not accessible [10]. There have been case reports with modifications to HD to try and increase the efficiency of toxin removal by using a high-cut-off dialysers which have been effective [7]. Sometimes the treatments can be combined: since phenytoin has a low volume of distribution and a well-adsorbent property to activated charcoal, HD can be combined with charcoal haemoperfusion [14]. HD may lead to a potentially toxic rebound phenomenon in 
highly protein-bound antiepileptic drugs such as valproic acid and phenytoin, although this did not occur in our patient; sustained low-efficiency daily dialysis has been demonstrated to prevent this rebound phenomenon in valproic acid toxicity [15]. A comparison of the advantages and disadvantages of various techniques used for extracorporeal drug removal is summarised in Table 1.

\section{Conclusion}

Phenytoin remains one of the most commonly used antiepileptic medications worldwide, and its pharmacokinetic properties can lead to unpredictable phenytoin levels leading to toxicity. For people with epilepsy on phenytoin who experience toxicity and who do not respond to conservative measures or are facing potentially life-threatening complications, our case adds to the evidence base that HD should be considered as an adjunct to lower phenytoin levels safely and efficaciously.

\section{Statement of Ethics}

Written informed consent was obtained from the patient's spouse.

\section{Disclosure Statement}

The authors have no conflicts of interest to disclose.

\section{Funding Sources}

None.

\section{Author Contributions}

K. Sharma was involved in writing the abstract, introduction, and discussion and in obtaining patient consent. A. Vakil was responsible for drafting the case summary and investigation results. A. Sokwala and D. Sokhi were responsible for conception of the work, critical revisions, and approving the final draft.

\section{References}

1 Wu MF, Lim WH, Pharm B, Pharm C. Phenytoin: A Guide to Therapeutic Drug Monitoring. Proc Singapore Healthc. 2013;22(3):198-202.

2 Iorga A, Horowitz BZ. Phenytoin toxicity (updated February 28, 2019). Treasure Island, FL: StatPearls Publishing; 2019. Available from: https://www.ncbi.nlm.nih.gov/books/NBK482444/. 
3 de Pont AC. Extracorporeal treatment of intoxications. Curr Opin Crit Care. 2007 Dec;13(6):668-73.

4 Heipertz R, Pilz H. Interaction of nitrofurantoin with diphenylhydantoin. J Neurol. 1978 Aug;218(4):297301.

5 Al-Khulaif AH, Shujaa AS. Phenytoin induced status epilepticus. Neurosciences (Riyadh). 2010 Apr;15(2): 131-2.

6 Gandhi S, McArthur E, Mamdani MM, Hackam DG, McLachlan RS, Weir MA, et al. Antiepileptic drugs and hyponatremia in older adults: two population-based cohort studies. Epilepsia. 2016 Dec;57(12):2067-79.

7 Cormier MJ, Desmeules S, St-Onge M, Ghannoum M. Phenytoin overdose treated with hemodialysis using a high cut-off dialyzer. Hemodial Int. 2017 Jan;21(1):E13-7.

8 Ghannoum M, Troyanov S, Ayoub P, Lavergne V, Hewlett T. Successful hemodialysis in a phenytoin overdose: case report and review of the literature. Clin Nephrol. 2010 Jul;74(1):59-64.

9 Robertson K, von Stempel CB, Arnold I. When less is more: a case of phenytoin toxicity. BMJ Case Rep. 2013 Mar;2013:bcr2012008023.

10 Anseeuw K, Mowry JB, Burdmann EA, Ghannoum M, Hoffman RS, Gosselin S, et al.; EXTRIP Workgroup. Extracorporeal Treatment in Phenytoin Poisoning: Systematic Review and Recommendations from the EXTRIP (Extracorporeal Treatments in Poisoning) Workgroup. Am J Kidney Dis. 2016 Feb;67(2):187-97.

11 Oltrogge KM, Peppard WJ, Saleh M, Regner KR, Herrmann DJ. Phenytoin removal by continuous venovenous hemofiltration. Ann Pharmacother. 2013 Sep;47(9):1218-22.

12 Sung SF, Chiang PC, Tung HH, Ong CT. Charcoal hemoperfusion in an elderly man with life-threatening adverse reactions due to poor metabolism of phenytoin. J Formos Med Assoc. 2004 Aug;103(8):648-52.

13 Sen S, Ratnaraj N, Davies NA, Mookerjee RP, Cooper CE, Patsalos PN, et al. Treatment of phenytoin toxicity by the molecular adsorbents recirculating system (MARS). Epilepsia. 2003 Feb;44(2):265-7.

14 Miller MA, Crystal CS, Patel MM. Hemodialysis and hemoperfusion in a patient with an isolated phenytoin overdose. Am J Emerg Med. 2006 Oct;24(6):748-9.

15 Khan E, Huggan P, Celi L, MacGinley R, Schollum J, Walker R. Sustained low-efficiency dialysis with filtration (SLEDD-f) in the management of acute sodium valproate intoxication. Hemodial Int. 2008 Apr;12(2):211-4. 


\section{Case Reports in Neurology}

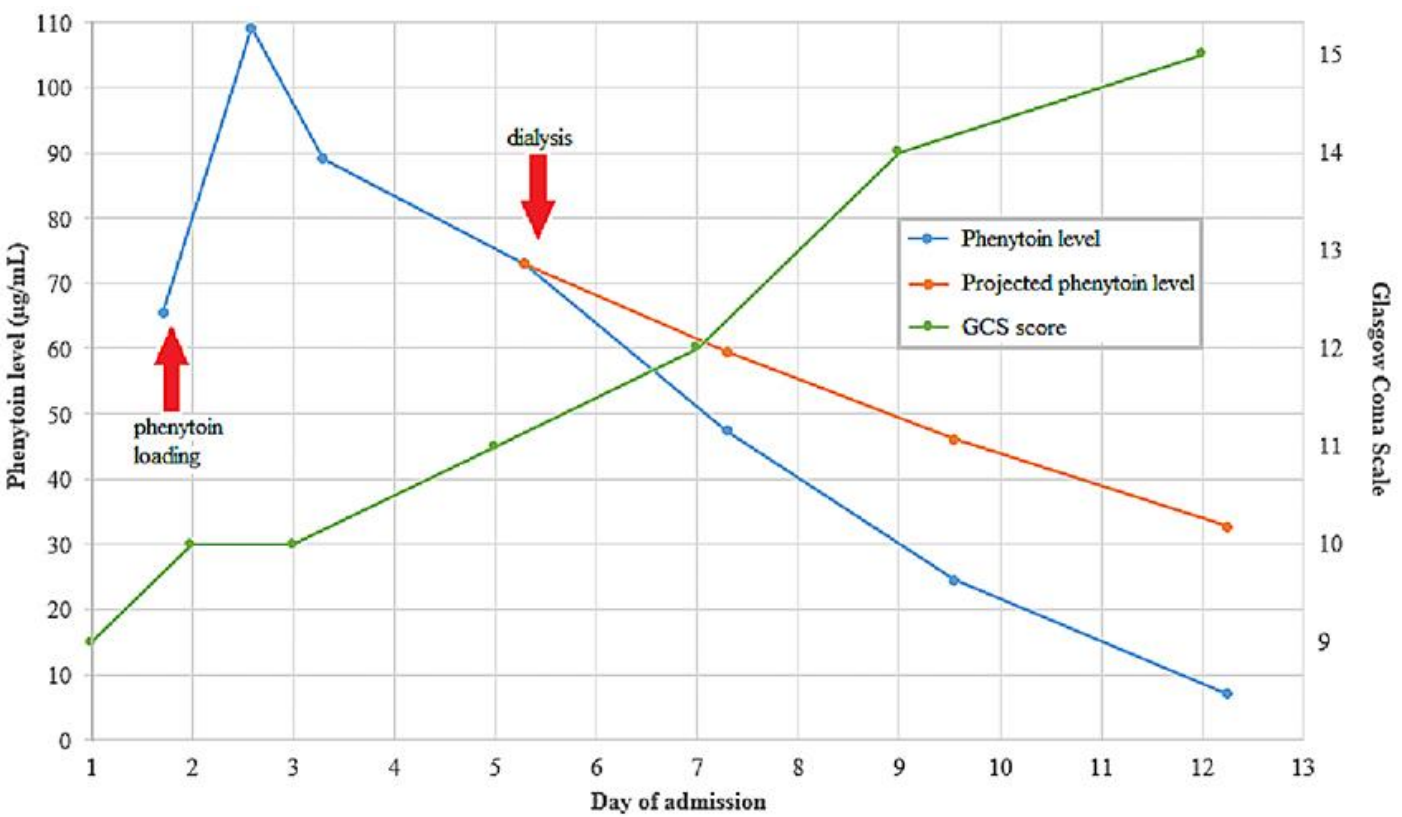

Fig. 1. The phenytoin, sodium, and Glasgow Coma Scale (GCS) score trends for our patient while in hospital.

Sharma et al.: Phenytoin Toxicity Treatment with Haemodialysis in Epilepsy due to Glioblastoma Multiforme: Case Report and Review of the Literature 
Table 1. Comparison of extracorporeal drug removal methods

\begin{tabular}{lll}
\hline Method & Advantages & Disadvantages \\
\hline $\begin{array}{l}\text { Charcoal } \\
\text { haemoperfusion }\end{array}$ & $\begin{array}{l}\text { high adsorption of toxins; not affected by } \\
\text { molecular weight, protein binding, or lipid } \\
\text { solubility }\end{array}$ & $\begin{array}{l}\text { limited availability; expensive; } \\
\text { short half-life }\end{array}$ \\
\hline $\begin{array}{l}\text { Molecular adsorbent } \\
\text { recirculating system }\end{array}$ & $\begin{array}{l}\text { effective for toxins with high albumin } \\
\text { binding }\end{array}$ & $\begin{array}{l}\text { limited availability; expensive; } \\
\text { slower clearance rate }\end{array}$ \\
\hline $\begin{array}{l}\text { Continuous } \\
\text { veno-venous } \\
\text { haemofiltration }\end{array}$ & $\begin{array}{l}\text { can be used in haemodynamically unstable } \\
\text { patients; effective for slow continuous } \\
\text { removal of toxins that have large volume } \\
\text { of distribution or extensive tissue binding; } \\
\text { useful even in case of delayed initiation; } \\
\text { avoids rebound toxicity }\end{array}$ & $\begin{array}{l}\text { in critical care (added cost); less } \\
\text { rapid elimination }\end{array}$ \\
\hline $\begin{array}{l}\text { Intermittent } \\
\text { haemodialysis }\end{array}$ & $\begin{array}{l}\text { readily available; no need to transfer to } \\
\text { critical care; effective for drugs with low } \\
\text { molecular weight, protein binding, volume } \\
\text { of distribution, and lipid solubility }\end{array}$ & $\begin{array}{l}\text { may require repeated sessions; } \\
\text { risk of rebound toxicity after } \\
\text { cessation of treatment }\end{array}$ \\
$\begin{array}{l}\text { Sustained } \\
\text { low-efficiency }\end{array}$ & $\begin{array}{l}\text { shorter sessions; cheaper than continuous } \\
\text { veno-venous haemofiltration }\end{array}$ & $\begin{array}{l}\text { less efficient than intermittent } \\
\text { haemodialysis; not suitable if } \\
\text { haemodynamically unstable; }\end{array}$ \\
\hline
\end{tabular}

Sharma et al.: Phenytoin Toxicity Treatment with Haemodialysis in Epilepsy due to Glioblastoma Multiforme: Case Report and Review of the Literature 